Samsung, Scipher, Set Point, Nancy Shadick Grant/research support from: Bristol-Myers Squibb, Sanofi/Regeneron, Crescendo Biosciences, Mallinckrodt, Amgen, Consultant for: Consulting work for Bristol-Myers Squibb for under \$10,000., Cecilie Heegaard Brahe Grant/research support from: Unrestricted grant: Novartis, Mikkel Ǿstergaard Grant/research support from: Abbvie, Celgene, Centocor, Merck, Novartis, Consultant for: Abbvie, BMS, Boehringer-Ingelheim, Celgene, Eli Lilly, Hospira, Janssen, Merck, Novartis, Novo, Orion, Pfizer, Regeneron, Roche, and UCB, Speakers bureau: Abbvie, BMS, Boehringer-Ingelheim, Celgene, Eli Lilly, Hospira, Janssen, Merck, Novartis, Novo, Orion, Pfizer, Regeneron, Roche, and UCB, Merete L. Hetland Grant/research support from: BMS, MSD, AbbVie, Roche, Novartis, Biogen, Pfizer, Consultant for: Eli Lilly, Speakers bureau: Orion Pharma, Biogen, Pfizer, CellTrion, Merck, Samsung Bioepis, Saedis Saevarsdottir Employee of: Part-time employee at deCODE Genetics/Amgen Inc, working on genetic research unrelated to this project., Megan Horton Employee of: Myriad Genetics, Inc., Brent Mabey Employee of: Myriad Genetics, Inc., Darl Flake Shareholder of: Myriad Genetics, Inc., Employee of: Myriad Genetics, Inc., Eric H. Sasso Shareholder of: Myriad Genetics, Inc., Employee of: Crescendo Bioscience, Inc., Thomas Huizinga Consultant for: Merck, UCB, Bristol Myers Squibb, Biotest AG, Pfizer, GSK, Novartis, Roche, Sanofi-Aventis, Abbott, Crescendo Bioscience Inc., Nycomed, Boeringher, Takeda, Zydus, Epirus, Eli Lilly

DOI: 10.1136/annrheumdis-2019-eular.6382

\section{THU0066 IN EARLY RHEUMATOID ARTHRITIS ANTI- CITRULLINATED PEPTIDE ANTIBODIES ASSOCIATE WITH LOWER NUMBER OF AFFECTED JOINTS, AND IGM RHEUMATOID FACTOR WITH SYSTEMIC INFLAMMATION IN AN ANTI-CITRULLINE DEPENDENT MANNER}

Eleftheria Pertsinidou ${ }^{1}$, Vivek Anand Manivel ${ }^{1}$, Lars Klareskog ${ }^{2}$, Lars Alfredsson ${ }^{3,4}$, Linda Mathsson ${ }^{1,5}$, Monika Hansson ${ }^{2}$, Martin Cornillet ${ }^{6}$, Guy Serre, Rikard Holmdahl ${ }^{7}$, Karl Skriner ${ }^{8}$, Per-Johan Jakobsson ${ }^{2}$, Helga Westerlind ${ }^{9}$, Johan Askling ${ }^{9}$, Saedis Saevarsdottir ${ }^{2,3}$, Johan Rönnelid'. ' Uppsala University, Department of Immunology, Genetics and Pathology, Uppsala, Sweden; ${ }^{2}$ Karolinska Institute, Rheumatology Unit, Department of Medicine, Solna, Stockholm, Sweden; ${ }^{3}$ Karolinska Institute, Institute of Environmental Medicine, Stockholm, Sweden; ${ }^{4}$ Stockholm County Council, Center for Occupational and Environmental Medicine, Stockholm, Sweden; ${ }^{5}$ Thermo Fisher Scientific, Uppsala, Sweden; ${ }^{6}$ U1056 Inserm, Toulouse University, Laboratory of Epithelial Differentiation and Rheumatoid Autoimmunity, Toulouse, France; ${ }^{7}$ Karolinska Institute, Department of Medical Inflammation Research, Stockholm, Sweden; ${ }^{8}$ Charité University Hospital, Department of Medicine, Berlin, Germany; ${ }^{9}$ Karolinska Institute, Department of Medicine, Solna, Stockholm, Sweden

Background: Recent studies have shown divergent associations between rheumatoid arthritis (RA)-associated autoantibodies and RA onset phenotype. Whereas some studies report more inflammation in seronegative patients [1, 2], others report that rheumatoid factor (RF) associates with high baseline disease activity [3].

Objectives: To define how individual RA-associated autoantibodies associate with individual disease activity score (DAS28, DAS28CRP) components at the time of RA diagnosis.

Methods: Sixteen individual ACPA reactivities, anti-CCP2, IgA-, IgG- and IgM-RF were analyzed centrally in baseline sera from 1600 RA patients classified according to the 1987 ACR criteria. All antibody cut-offs were determined as the $98^{\text {th }}$ percentile among controls. The results were related to CRP, ESR, number of swollen and tender joints, DAS28, DAS28CRP, global disease activity (visual analogue scale), and health assessment questionnaire obtained at baseline.

Results: Individually, anti-CCP2, IgA RF and IgM RF associated with low counts of swollen and tender joints, with strongest association to antiCCP2, and with high ESR. The association to low joint counts was stronger to number of individual ACPA reactivities than to anti-CCP2 levels (table). In multiple regression adjusted for age, sex and inclusion year, ACPA number associated strictly with low joint counts whereas IgM RF level associated with increased inflammatory markers, especially ESR (table). Also among IgM RF negative patients, occurrence of ACPA associated with low swollen and tender joint counts. Contrary, among ACPA negative patients, IgM showed no association to elevated ESR. The
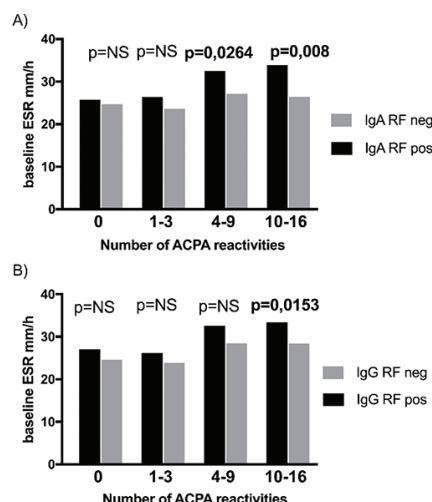

C)

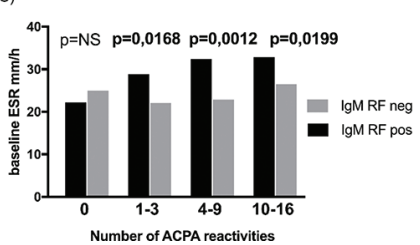

Abstract THU0066 - Figure 1

effect of RF on ESR increased with the number of individual ACPA reac tivities present, most prominently for IgM RF (figure).

Conclusion: In early RA, ACPA associate with low counts of affected joints and IgM RF associates with elevated ESR in an ACPA-dependent manner. The latter finding relates to in vitro studies showing enhanced inflammatory effect of ACPA immune complexes with addition of $\operatorname{RF}[4,5]$. Future RA studies relating autoantibodies to disease activity may benefit from evaluating the impact of individual antibodies as well as distinct DAS components separately.

\section{REFERENCES:}

[1] Barra L, et al. J Rheumatol 2014;41:2361.

[2] Nordberg LB, et al. Ann Rheum Dis 2017;76:341

[3] Aletaha D, et al. Arthritis Res Ther 2015;17:229.

[4] Laurent L, et al. Ann Rheum Dis 2015;74:1425.

[5] Sokolove J, et al. Arthritis Rheumatol 2014;66:813.

\begin{tabular}{|c|c|c|c|c|}
\hline & IgA RF & IgG RF & IgM RF & ACPA \\
\hline $\begin{array}{l}\mathrm{N}(\%) \text { antibody } \\
\text { positive }\end{array}$ & $692(43.2)$ & $529(33.1)$ & $916(57.2)$ & $1020(63.8)$ \\
\hline \multicolumn{5}{|l|}{ Multiple regression: } \\
\hline CRP P value $(\beta)$ & $\begin{array}{l}0.6914 \\
(0.011)\end{array}$ & $\begin{array}{c}0.3162(- \\
0.026)\end{array}$ & $0.0106(0.071)$ & $0.6889(0.011)$ \\
\hline ESR P value $(\beta)$ & $\begin{array}{l}0.0215 \\
(0.062)\end{array}$ & $0.1237(0.039)$ & $\begin{array}{c}<0.0001 \\
(0.108)\end{array}$ & $0.0380(0.057)$ \\
\hline SJC P value $(\beta)$ & $\begin{array}{l}0.6175 \\
(0.013)\end{array}$ & $\begin{array}{c}0.2110(- \\
0.032)\end{array}$ & $0.0645(0.051)$ & $\begin{array}{c}<0.0001 \\
0.122)\end{array}$ \\
\hline TJC P value $(\beta)$ & $\begin{array}{l}0.6168 \\
(0.014)\end{array}$ & $\begin{array}{c}0.4120(- \\
0.021)\end{array}$ & $0.8712(0.005)$ & $0.0007(-0.094)$ \\
\hline
\end{tabular}

Disclosure of Interests: Eleftheria Pertsinidou: None declared, Vivek Anand Manivel: None declared, Lars Klareskog Grant/research support from: Yes, but not for the presented study., Lars Alfredsson: None declared, Linda Mathsson Employee of: employed by Thermo Fisher Scientific, Monika Hansson: None declared, Martin Cornillet: None declared, Guy Serre: None declared, Rikard Holmdahl: None declared, Karl Skriner: None declared, Per-Johan Jakobsson: None declared, Helga Westerlind: None declared, Johan Askling Grant/research support from: Karolinska Institutet (JA) has or has had research agreements with the following pharmaceutical companies, mainly in the context of the ATRIS national safety monitoring programme for rheumatology biologicals: Abbvie, BMS, MSD, Eli Lilly, Pfizer, Roche, Samsung Bioepis, and UCB., Consultant for: Karolinska Institutet has received remuneration for JA participating in ad boards arranged by Lilly, Novartis, and Pfizer., Saedis Saevarsdottir Employee of: Part-time employee at deCODE Genetics/Amgen Inc, working on genetic research unrelated to this project., Johan Rönnelid: None declared

DOI: 10.1136/annrheumdis-2019-eular.3025 